\title{
Sticks, Stones, and the Secular Bones of Indian Democracy
}

\author{
MONAMIE BHADRA HAINES ${ }^{1}$ \\ NANYANG TECHNOLOGICAL UNIVERSITY \\ SREELA SARKAR ${ }^{2}$ \\ SANTA CLARA UNIVERSITY
}

\begin{abstract}
While being inspired by the compelling social protests against the Citizenship Amendment Act and National Register of Citizens in India, the authors of this critical engagement argue that now, more than ever, is time to reflect on the nature of secularism that is being invoked by nonviolent protesters. What can a focus on lathi-wielding and stone-throwing, all low technologies of governance, tell us about the practices and challenges of liberal democracy in India? This piece excavates a brief history of the lathi and stone-pelting to show what kinds of "illiberal" protests are deemed aesthetically pleasing and palatable to elites in India and abroad, which ones are not, and the dangers of this kind of exclusion with respect to new forms of Islamophobia.
\end{abstract}

\section{Keywords}

India; social movements; Citizenship Amendment Act; Islamophobia

Over the past two weeks, the media has been afire with anecdotes and analysis of the premeditated and organized violence inflicted upon the Muslim community in New Delhi by Hindu nationalists during Donald Trump's visit to the city. The terror and tragedy experienced by the Muslim community, whose bodies, businesses, and homes were beaten and burnt almost erases from memory all that came before-the ramping up of police violence against largely

\footnotetext{
${ }^{1}$ Monamie Bhadra Haines, Email: monamie.haines@ntu.edu.sg

25reela Sarkar, Email: ssarkar@scu.edu

Copyright (C) 2020 (Monamie Bhadra Haines, Sreela Sarkar). Licensed under the Creative Commons Attribution Noncommercial No Derivatives (by-nc-nd). Available at estsjournal.org.
} 
nonviolent protests against the Citizenship Amendment Act of 2019 and the National Register of Citizens, which, together, would effectively strip particularly poor Muslims of their Indian citizenship.

That state-sanctioned, brutal violence has been part of India's political culture since its bloody colonization and is part of the DNA of Indian democracy is well-known. But what can the technologies of everyday violence used by the Indian state and protesting citizens-the lathi and the stone-reveal about the workings of and commitments to Indian democracy, as well as claims to citizenship? While the nonviolent protests affirming Indian secularism are undoubtedly powerful, inspiring, and visceral, they also throw open questions of class and religious based inclusions/exclusions in modern India including whose rights of protest and what forms of resistance are deemed acceptable by the more elite classes.

Before the recent pogroms against Muslim communities, countless videos of the police beating nonviolent protesters in India who oppose the CAA and NRC were flooding social media. Prominently featuring in many of the videos were the lathi and the stone for throwing, where the lathi is an approximately 1.8-meter length of tempered-bamboo or plastic pole. As lowtech instruments of policing and protest, the lathi and the stone, respectively, stood in stark contrast to facial recognition technologies, tear gas and guns that were part of the repertoire to thwart activists and protesters in Hong Kong, and guns and tasers that kill Black men, women, and children in the United States, even as they later became more prominent prior to the antiMuslim violence in the wake of the protests against CAA and NRC.

\section{Weaponizing the Lathi}

As most endeavors seeking to understand the postcolonial Indian state, it is instructive to begin with Britain's colonization of India. Scholars like Gloria Goodwin Raheja at University of Minnesota have shown how the colonial state weaponized the lathi found in native proverbs like "jiski lathi, uski bhains" (who owns the lathi, the buffalo is theirs) to justify violent suppression against a native populace that was taken to be inherently violent. Regardless of the many other uses of the lathi-as a tool of cowherding and navigating the surrounding terrain, for example, beyond its utility to hit-colonial governance fixated on the lathi as evidence of coercive power latent within native communities. All of this proved to be a self-fulfilling prophecy as the British identified the lathi as the weapon of choice for its Indian, imperial armed forces. Scholars studying the arming of India's police force have noted the importance of the lathi in modern, mainstream Hinduism, stemming from anti-imperial agitation in the 1900s. In the 1920s, Indians 
who were part of Britain's colonial armed forces had their truncheons taken away in favor of lathis because the former were seen as "unsuitable for Indian policemen," and consequently trained in extensive "lathi-play." Even in the former British colony of Singapore, where one of the authors lives, the Singaporean government discussed the possibility of its police force carrying the lathi instead of the defensive T-baton to better police the largely Bangladeshi and South Indian migrant workers living in Little India after the 2013 "riots" because it would be more culturally appropriate.

Weaponizing the lathi became complete when it was reworked through Hindu ideological circuits. Scholars like Arafaat Valiani, of University of Oregon, have shown how, during the rise of anti-colonial protests, the Hindu nationalists like the Rashtriya Swayamsevak Sangh (RSS) regarded expertise with the lathi as an ancient and sacred Vedic martial art. Local branches of the RSS used lathi-training in neighborhood gyms to create a sense of camaraderie, community, and common moral purpose among its constituents who were largely low-to-middle caste Hindu men, thus helping to consolidate RSS power. According to Valiani, RSS chapters viewed the physical culture around the lathi as a way to undermine the stereotype of effete Indian males, gain moral authority through self-discipline oriented towards helping one's Hindu community, and thereby allowing low-caste Hindus to make claims to high-caste Hindu virtue. Even high-ranking members of Gandhi's nonviolence movement, which was the pinnacle of upper-class and caste morality, saw the RSS discipline as something to be admired. Gandhian leaders tried to inculcate a similar program of physical discipline to produce followers who needed to develop the necessary mental and physical fortitude to withstand the lathi blows during peaceful protests. Today, the lathi carries with it this colonial and religious legacy. The weaponized lathi is once more a tool of Hindu nationalism, but this time aligned with the repressive state, and not against.

\section{Lathi Culture and India's Police}

Much like guns in America, the lathi can be easily purchased online, such as the anti-riot equipment in Indiamart where one has $\underline{\text { bamboo }}$ or polycarbonate options. But Delhi has a robust bamboo and polycarbonate lathi manufacturing industry, even as many bamboo lathis come from the Northeastern states of Assam and Tripura-incidentally where the lathi is used to facilitate the disenfranchisement of local citizens. While the authors are unaware of the exact material practices of choosing and circulating lathis, a closer look at the videos of Indian police helps us understand how the lathi figures in Indian politics. 
The first thing one notes when watching with horror the "lathi-charges" is how the lath $i$ is an indiscriminate tool for both maiming and killing. The lathi-wielders gravitate toward fallen individuals, and, like the grisly gang-rapes in India (even in December 2019), take turns breaking and wounding, not taking pains to prevent death. Feminist and disability studies scholar Jasbir Puar writes about what she calls the politics of debilitation, or maiming. For Puar, debilitation means that the state intentionally refrains from killing, but instead opts for maiming, to make itself seem more humanitarian. The lathi is not caught up in such politics of maiming by design. The Indian state under the Modi government does not care whether the people targeted by the lathi are maimed or killed, only that they are cowed to submission.

The second aspect of police-protester clashes one observes is how wielding the lathi is a game. The lathis become the appendages of the policemen, their joysticks to maximize blows in the game of beating unsuspecting humans and objects alike. Lathi-play is not just confined to informal, low-class neighborhood organizations, or in training exercises. Wielding the lathi is a game the police play to demonstrate their ingenuity in leveling a jab into the holes created by desperately shielding limbs or reaching to smash a head or thigh of fleeing protesters. Moreover, lathiplay requires would-be targets to be equally agile in playing this game, which most, of course, are not. Lathi as an arbitrary game brings to mind fascist forces who wield terror with impunity.

The third aspect observers might acknowledge is that the lathi is not merely sadistic play, but also work. One is drawn to the relative dispassion of the police in videos, and even their weariness, as they go about damaging people and property. Like children picking up sticks and idly hitting trees and leaves whilst walking, Indian policemen trudge through neighborhoods slowly, hitting cars, houses, windows-whatever is in their reach-leaving lackadaisicallywrought destruction in their wake. One is reminded that an Indian police officer makes only a pittance for salary. Wielding the lathi requires a physicality, a perspiration-filled labor. It seems almost as if the police are damaging property for the sake of being able to say they hit something. As work, the lathi follows a procedural logic, like bureaucratic box-checking — hitting something even with a desultory blow fulfills some directive from on high that requires violence of the police, all of whom tend to be underpaid and overworked.

The lathi, then, is evidence of the illiberalism of Indian democracy, especially in light of the liberal secularism of the national-scale anti-CAA and anti-NRC protests that have mobilized in response to the lathi. But this is only a partial picture. One must also account for what kinds of illiberalism are allowed and when it breaks the proverbial camel's back, as well as what other 
kinds of nonliberalism must be discounted and repressed. For this, we need to look at the history of the stone in Indian politics to understand the stakes of India's democracy.

\section{The Stone and Indian Secularism}

Initially, many protesting the CAA have met the power of the lathi by pelting stones, an even more primitive technology that has been historically been used as a form of resistance against the Indian state in Kashmir through Kanni Jung (stone war) and in other places, like Palestine. Since 1931, stone throwing against the lathi wielding military and police has been common in Kashmir where the Indian state considers Kanni Jung as a criminal assault, and a gateway tool to armed terrorism. Indeed, Kashmir studies scholars take issue with using the phrase "stone pelting" as opposed to the colloquial Kanni Jung. "Stone pelting" simplifies Kashmiris into indoctrinated youths who break the law, whereas "Kanni Jung" used on the streets of Kashmir acknowledge a history of oppression against which women and youth actively engage in protest by picking up stones.

Kanni Jung as a form of resistance has intensified after the 2008 Kashmir protests. Stone throwers include youth as well as women who protest the deaths and abduction of family members, making the stone a symbol of powerless anger. In popular culture, stone throwers are celebrated as heroes and as dreamers who work against the harsher weapons, namely guns, of the police. The Indian state has labeled stone throwing in Kashmir as "gunless terrorism," and have even attempted to blind stone throwers through lead pellet guns. Stone throwers were prominent in the valley during the protests against the Modi government's recent decision to revoke Jammu and Kashmir's constitutional authority.

But stone throwing is certainly not confined to Kashmir against Indian militarism and oppression. In the north-east of Delhi, Seelampur where one of the authors has conducted fieldwork over the years, a majority of working-class, Muslim residents have a long history of picking up stones as a symbol of powerless anger, with the latest focus on the CAA. Seelampur was mainly settled in the National Emergency years in the 1970s when Muslim men were sterilized in exchange for small plots of land and for keeping families together. In 2006, manufacturing industries in the area dealing with the production of jeans, iron, timber goods, incense, and lathes were deemed "polluting units" by the state and shut down. This "bourgeoise environmentalism" protected upper-class concerns over aesthetics and "safety" but resulted in massive loss of livelihood in Seelampur with no compensation. In response to the police's lathi and bullets, residents who protested these actions wielded stones. Despite the state violence, the 
stone throwers were labeled as "lumpen elements," a "rampaging mob," and the "capital city's social underbelly," as is evident in the recent anti-CAA protests in Seelampur, when the police lathi-charged and used tear gas against hundreds of protestors who were reported as stonepelting mobs.

Most recently, Jaffrabad, the neighborhood that is considered part of the larger Seelampur locality, has been a major target of the anti-Muslim pogrom in Delhi that started at the same time as Trump's visit to India. Hindu mobs carrying lathis, stones, guns, and saffron flags maimed and killed Muslims in Jaffrabad and adjoining neighborhoods. Hundreds of Muslims were injured and brought to poorly equipped hospitals. Corpses continued to be found in drains in the neighborhoods. Protestors hurled stones at both the police and the Hindu mob who colluded with one another. This largely symbolic form of protest against a draconian state has parallels to earlier protests in Jaffrabad against the closure of manufacturing industries and to Kashmiri stone throwers.

The spectacle of violence in the Delhi pogrom invited more empathy from elite, Hindu residents of Delhi who heard of or visited certain neighborhoods in North-East Delhi for the first time, but did not necessarily make connections between the current situation to the history of violence against residents in these neighborhoods or to the actions of the Sangbaaz or stone throwers in Kashmir who remained largely distant in the popular imagination. Present configurations around stone throwing in Seelampur and Jaffrabad signaled to related struggles of Muslims in Delhi and Kashmir and Uttar Pradesh and globally, but perhaps only received more sympathy from elite classes when the excess of violence paralyzed everyday life in Delhi and became impossible to ignore. However, representations of "stone throwers" in Delhi continued to signal the violent protestors rather than the resistance of the Kanni Jung.

\section{Separating Stones from Secular Satyagraha}

Such "unruly protesters" of stone-throwing Muslims stand in stark contrast to aesthetics of secularism and nonviolence or Gandhian satyagraha being mobilized by the largely upper-caste, left-leaning liberal students. In the popular Indian imagination, stone-throwing is an example of illiberal, religious-based protest, whereas satyagraha is the enlightened-although not necessarily liberal because it is extraparliamentary and seemingly nondeliberative-protest of the elite against a lathi-wielding state. "Solidarity from [Indian] liberals is conditional," Mudasir Amin and Samreen Mudhtaq write in a sharp and incisive article, "because of their understanding of Muslims as quintessentially illiberal. The liberals boast about the country's pluralistic credentials, 
but see any assertion on part of Muslims who foreground their identity in religious terms as inimical to India's secular fabric."

The authors note that in Jamia Milia Islamia (National Islamic University, (JMI)) in Delhi, the day before the police laid siege on university students and beat them indiscriminately, leftist students were painting over Muslim slogans scrawled on a wall that they deemed to be communal-Allahu Akbar-and shouting down speakers who were trying to argue that CAA and the NRC were about anti-Islam politics.

The internal rifts over communalism and secularism within JMI played out on a larger scale when the police lathi-charged and used teargas on protesting students in December 2019. Student protestors of JMI were reported to pelt stones while the police used lathi charge and tear gas grenades. Elite residents who lived in a gated community nearby JMI, The Residents Welfare Association, responded to the stone-pelting — not the police violence- by filing a complaint that during the protests miscreant students had damaged public property and "disturbed peace" in the area. Even though other institutions like the elite Indian Institute of Management in Ahmedabad launched protests in solidarity with JMI, the suffering of the JMI students was largely rendered as "Other" in the popular Indian imagination. What happened in JMI was of the same piece as what goes on in Seelampur or Kashmir or any other historically-Muslim community that faces clashes with the state in a continual basis.

Again, such ideas of secularism have roots in colonization. Noted religious studies scholar, Talal Asad, and those drawing on his insights, make exactly this argument: secularism is an invention and the product of boundary work by colonial elites to demarcate between secular scientific reason and superstition, where articulating differences in people shifted from talking about religious differences to secular, racial differences grounded in science. Along these lines, Amin and Mudhtaq ask, "What is it about Muslim (religious) assertion that must be repressed in order to forge unity with leftist-liberals?...How is it that Muslims asserting their Indian identity are welcome, but those asserting their religious identity beyond the liberal framework are silenced? If the people are out on the streets to protect the secular values of the country as enshrined in the Constitution, do those values necessitate for religion to be sidelined-disallow Muslimness in any form in the public sphere, even when the exclusion is clearly about Muslim identity?" All vital and deeply uncomfortable questions about the newest expression of Islamophobia in a progressive, secular garb.

It was only when a masked crowd armed with lathis, iron rods, and bricks entered the prestigious Jawaharlal Nehru University (JNU) maiming students in January 2020 that uppermiddle class anger against the CAA and NRC spilled over into the nonviolent mass movement 
India is experiencing today. At JNU, the lathi was no longer the symbol of the state's disciplinary power, but rather understood to represent the mob mentality of low-class and probably low-caste hooligans in the view of peaceful anti-CAA protesters who could come after the elites. Thus, the Hindu Right's attempt to portray the JNU "leftists" and "Naxals" (India's Maoist revolutionaries) as stone throwers-the term specifically associated with Muslim protesters-backfired spectacularly, and propelled more elite liberals in Delhi and in other cities in India to participate in larger scale demonstrations in support of JNU and the idea of secularism. These expressions of support for JNU students possibly mirrored the dominance of upper-caste faculty and student leaders on campus. But the notable silence among this same group when the Modi government decided to revoke Kashmir's autonomous status sent a clear message: take our Muslims, but leave our communists alone.

As opposed to the stone throwing, protests such as those in Shaheen Bagh (the locality of JMI) have been applauded as "a new kind of satyagraha with a new grammar of protest," referring to the Gandhian tactic of passive, political resistance. The Shaheen Bagh protestors are by no means homogenous in terms of class, gender, and religious identities, but there is a way that the protests appear more globally palatable and authentic than the Seelampur or Kashmir ones. Reports about Shaheen Bagh have focused on "women in hijabs" leading the protests as well as young people. For example, a popular article was taken with "a young, slim girl student" in pants who spoke at the Shaheen Bagh protests. Seelampur protestors were positively affirmed on news and social media when hundreds of women and children gathered on the streets, aided by Delhi University students. To draw a stark contrast, a sit-in by women in Jaffrabad prompted the Bharat Janata Party (BJP) politician, Kapil Mishra, to incite the police in actions that precipitated the Delhi pogrom.

The reports of the well-organized, largely leaderless protests are also reminiscent of accounts of global protests such as the Arab Spring and Occupy and Hong Kong. In a parallel example, the popularity of a video on social media of women protestors in Kolkata singing the Bengali version of the Chilean piece "the rapist is you" against Modi testifies to perhaps more acceptable and aestheticized forms of protest than the Seelampur stone thrower engages in, and indeed obscures the systematic sexual violence used by the state in the Northeast of India, and the powerful protests emerging there.

Historically, India has taken a cultural compartmentalization approach of allowing its mind-boggling cultural diversity to coexist in museumized form, and trying to keep it separate from centralized politics, which in turn were kept separate from technocrats-the nuclear establishment being a prime example. But as any scholar worth their salt march knows, politics, 
culture, and knowledge production, even the most technical sort, influence one another. The question India grapples with, then, is an old one: how do we honor pluralism of caste, culture, and religion without falling into the exclusionary politics of liberalism? Why can't Muslim religious identity be incorporated into secularism? While the Hindu Rashtra (or a Muslim caliphate for that matter) are most definitely not the answer, secularism, as it is articulated in its liberal form, is not enough either. Secular liberalism and pluralism tolerates only certain forms of diversity in India. But creating a form of protest that unites stone and satyagraha in common cause against the lathi may still be unimaginable.

\section{Author Biography}

Monamie Bhadra Haines is a writer, hobby artist, and an Assistant Professor in Global Science and Technology Studies at Nanyang Technological University. As an STS scholar she is particularly interested in the intersections of activism and the politics of knowledge around energy futures in nonliberal democratic contexts. She is currently writing a book on anti-nuclear activism in India, and is turning her attention to solar energy development in refugee camps.

\section{Author Biography}

Sreela Sarkar is an Assistant Professor in the Department of Communication at Santa Clara University. Her research studies the institutional and cultural politics of technology-led modernization programs aimed at "skilling India" for marginalized communities through ethnographic work in north-east Delhi. Her work appears in several feminist and media studies journals. Her current book project critically examines the politics of philanthropy in Silicon Valley through ethnographic work on the habitus of desi, social entrepreneurs.

\section{Acknowledgements}

We would like to thank the reviewer of this piece for their encouragement and insightful comments that have helped strengthen our arguments. 